\title{
PLA2G6 wt Allele
}

National Cancer Institute

\section{Source}

National Cancer Institute. PLA2G6 wt Allele. NCI Thesaurus. Code C49375.

Human PLA2G6 wild-type allele is located in the vicinity of 22q13.1 and is approximately $75 \mathrm{~kb}$ in length. This allele, which encodes $85 \mathrm{kDa}$ calcium-independent phospholipase A2 protein, plays a role in the hydrolysis of phosphatidylcholine. 